\title{
Active seeps and carbonates from the Kamchatsky Gulf (East Kamchatka)
}

\author{
N. I. SELIVERSTOV, P. I. TOROKHOV, YU. O. EGOROV, V. N. DUBROVSKY, YU. A. TARAN \\ \& S. G. KOKAREV
}

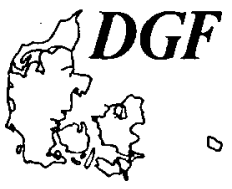

Seliverstov, N. I., Torokhov, P. I., Egorov, Yu. O., Dubrovsky, V. N., Taran, Yu. A. \& Kokarev, S. G.: Active seeps and carbonates from the Kamchatsky Gulf (East Kamchatka). Bulletin of the Geological Society of Denmark, Vol. 41, pp. 50-54, Copenhagen, 1994-03-30. https://doi.org/10.37570/bgsd-1995-41-05

\begin{abstract}
A zone of submarine gas seepages was discovered on the seafloor of the Kamchatsky Gulf (East Kamchatka). Gas plumes have been detected in the upper part of the Kamchatsky canyon within a depth range of $40-250 \mathrm{~m}$. Sandstones with carbonate cementation were recovered from the seafloor near the seep locations. Cement occurs as calcite and Mg-calcite. the isotopic composi-tion of carbon from carbonates $\left(\delta^{13} \mathrm{C}=-62 \%\right.$ o PDB provides grounds for believing that they originate as a result of methane oxidation.
\end{abstract}

N. I. Seliverstov, P. I.Torokhov, V. N.Dubrovsky, \& S. G.Kokarev, Institute of Volcanology, Petropavlovsk-Kamchatsky, 683006, Russia. Yu. O. Egorov \& Yu. A. Taran, Institute of Volcanic Geology and Geochemistry, Petropavlovsk-Kamchatsky, 683006, Russia. August 28th, 1992.

\section{Introduction}

Submarine plumes detected with echo sounders can be attributed to a number of factors, including hydrothermal activity, hydrocarbon-rich water discharge or hydrocarbon gas penetration through a zone of disturbance to the seafloor and into the water column. During recent years, oceanographers and marine geologists have shown a keen interest in these phenomena (Hovland \& Judd 1988); thus each new find is of great interest.

Prior to 1991, only two zones of fluid discharge to the seafloor had been studied in detail in offshore Kamchatka. In both cases, these zones were detected by recording gas plumes with echo sounders.

The first of these zones is located to the west of Paramushir Island. Gas plumes were located at a depth of about $800 \mathrm{~m}$. Studies were made during cruises 13 (1981), 15 (1982) and 24 (1985) of the R/V "Vulkanolog" and R/V "Akademic Mstislav Keldysh" (1985) using the submersible PISCES. The origin of plumes was largely attributed to hydrothermal activity (Avdeiko et al. 1984). However, further studies have demonstrated that the gas plumes are associated with cold methane seepages (Zonenshain, Murdmaa, Baranov, Kuznetsov, Kuzin, Kuzmin, Avdeiko, Stunzhas, Lukashin, Barash, Valyashko \& Demina 1987) that are confined to the zone of gas hydrate generation in sediments (Nadezhny \& Bondarenko 1989).

The second zone was detected in 1986 during cruise 26 of the R/V "Vulkanolog" near the summit of Piip submarine volcano at a depth of about $400 \mathrm{~m}$. Detailed studies were carried out in this region during cruises 28 (1987), 32 (1988) and 35 (1989) of the R/V "Vulkanolog" (Seliverstov, Baranov, Egorov and Shkira 1988; Seliverstov, Gavrilenko \& Kirianov 1989). Subsequent explorations were performed using the submersible "Mir" during cruise 22 of the R/V "Akademik Mstislav Keldysh" in 1990. It has been revealed that the gas plumes are confined to high-temperature hydrothermal vent fluids which have a high methane content. Low-temperature active hydrothermal vents showing no gas emissions were detected at a depth of about $500 \mathrm{~m}$ (Torokhov, Taran, Sagalevich, Pokrovsky \& Shabayeva 1991). In the spring and autumn of 1991, a further zone with gas manifistations was discovered and partially investigated during cruises 39 and 41 of the R/V "Vulkanolog". This zone is located in the northern Kamchatsky Gulf (East Kamchatka). Gas plumes were recorded at relatively shallow depths (40-250 m) (Nadezhny, Seliverstov, Torokhov, Egorov, Dubrovsky, Taran, Kokarev \& Shkira 1992).

\section{Methods}

Studies were made using echo sounding and seismic profiling with orthogonal lines generally with a 1 mile line spacing but with a $0.3-0.5$ mile line spacing at gas plume sites. Two echo sounders were utilized: WD-110M (KAJODENKI, Japan) with a central frequency of 12.5 $\mathrm{kHz}$, and JVF-820C (JCR, Japan) with frequencies of 28 $\mathrm{kHz}$ and $200 \mathrm{kHz}$. A one-channel sparker with a $1 \mathrm{~s}$ 

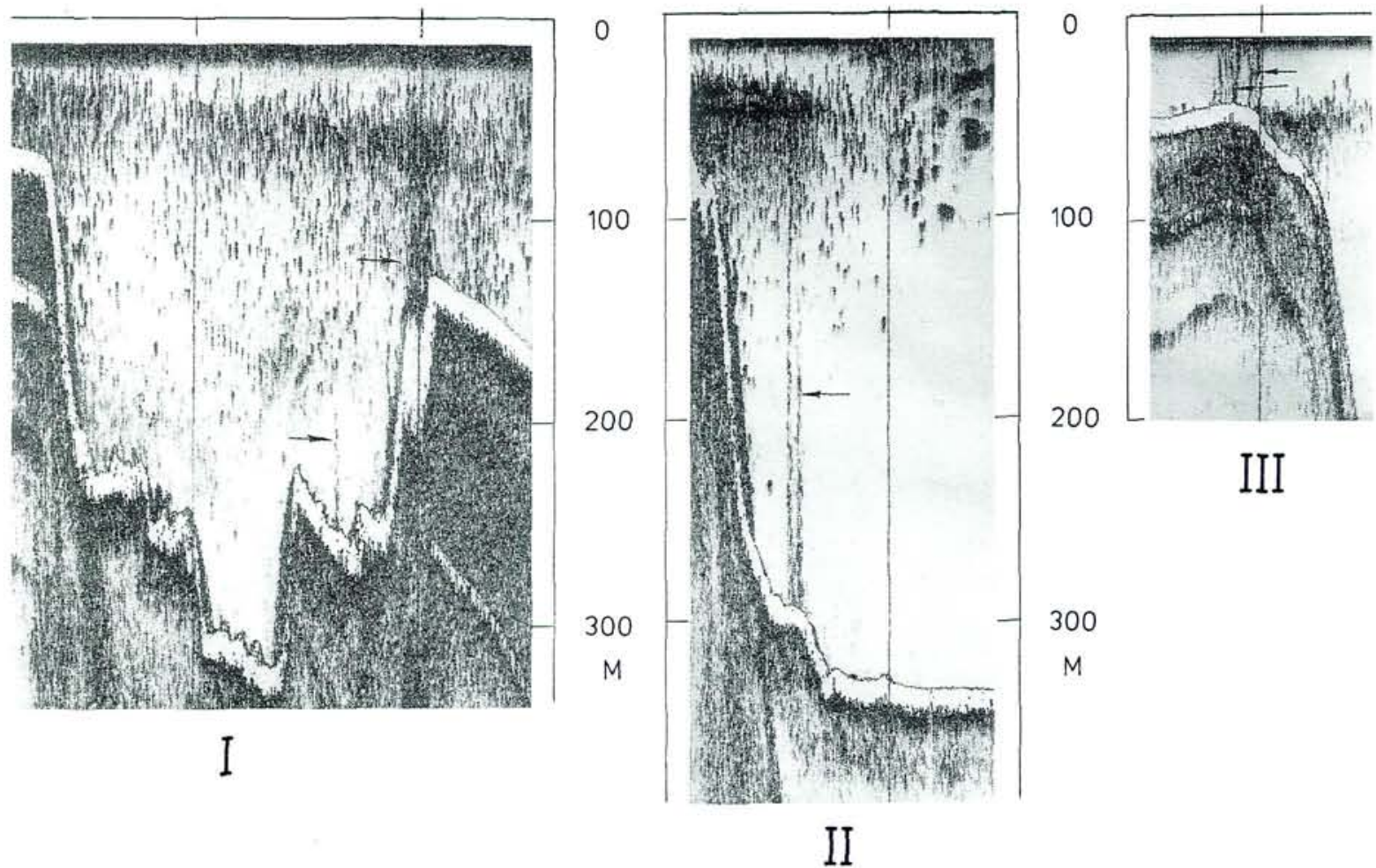

M

Fig. 1. Examples of echograms showing the gas plumes (designated by arrows). The position of corresponding profile portions is shown in Fig. 2. Records were obtained on the WO-110 echo sounder at a rate of 5 knots (profile I) and 3 knots (profiles II and III).

radiation period and a central seismic frequency of 150 $\mathrm{Hz}$ was used.

Studies included geological sampling at sites of gas plume discovery. Samples were collected in a dredge and ground tube. Clay samples recovered were explored for diatom remains, for mineral composition and cements (samples of sandstones, crusts and concretions). Also, we studied the carbon and oxygen isotopic composition of carbonate cements of recovered crusts and concretions. The most recent investigations were performed in the Isotope Laboratory of the Geological Institute of the Russian Academy of Sciences (Moscow) on the MI-1201B mass spectrometer. The estimated precision of measurements is $\pm 0.2 \%$. Carbonates were decomposed in orthophosphoric acid. The $\delta^{13} \mathrm{C}$ and $\delta^{18} \mathrm{O}$ values are given with respect to the PDB standard. The carbonate mineral composition was determined using a DRON-3M $\mathrm{X}$-ray diffractometer equipped with an IBM/PC.

\section{Results and discussion}

The plumes were located with echo sounder recorders during geophysical surveys while the vessel was in motion. Examples of WD-110M echograms showing the plumes are shown in Fig. 1.
During the geological investigations, when the vessel drifted slowly, a distinct oblique banding resembling that found over the gas plumes of the Piip submarine volcano (Seliverstov et al. 1989) was observed on the echograms. The value of band obliquity was constant. It corresponds to a rate of gas bubbles velocity of about $20 \mathrm{~cm} / \mathrm{s}$, which is characteristic of gas bubbles with a resonance frequency of $12.5 \mathrm{kHz}$. These data imply that the plume recorded in the given region is due to gas bubbles rising to the surface.

Most plumes detected in the northern Kamchatsky Gulf are confined to the marginal portions of a submarine valley representing a north-west offshoot of the Kamchatsky canyon. The location of this valley and a block diagram are shown in Fig. 2. The valley is slightly elongated to the north-west. It is about $10 \mathrm{~km}$ long and $6 \mathrm{~km}$ wide. It has a trough-shaped transverse profile with rather steep slopes (occasionally exceeding $30^{\circ}$ ) containing a number of scarps and cirques. The height of its walls is 200-250 $\mathrm{m}$ above the floor of the valley. The floor is a relatively flat surface sloping slightly $\left(3^{\circ}\right)$ to the southeast.

The seismic profiling and geological sampling data indicate that the south-west wall of the valley formed in the clay strata. The clay samples dredged from the scarps of the south-west wall at a depth range of 180-250 m 


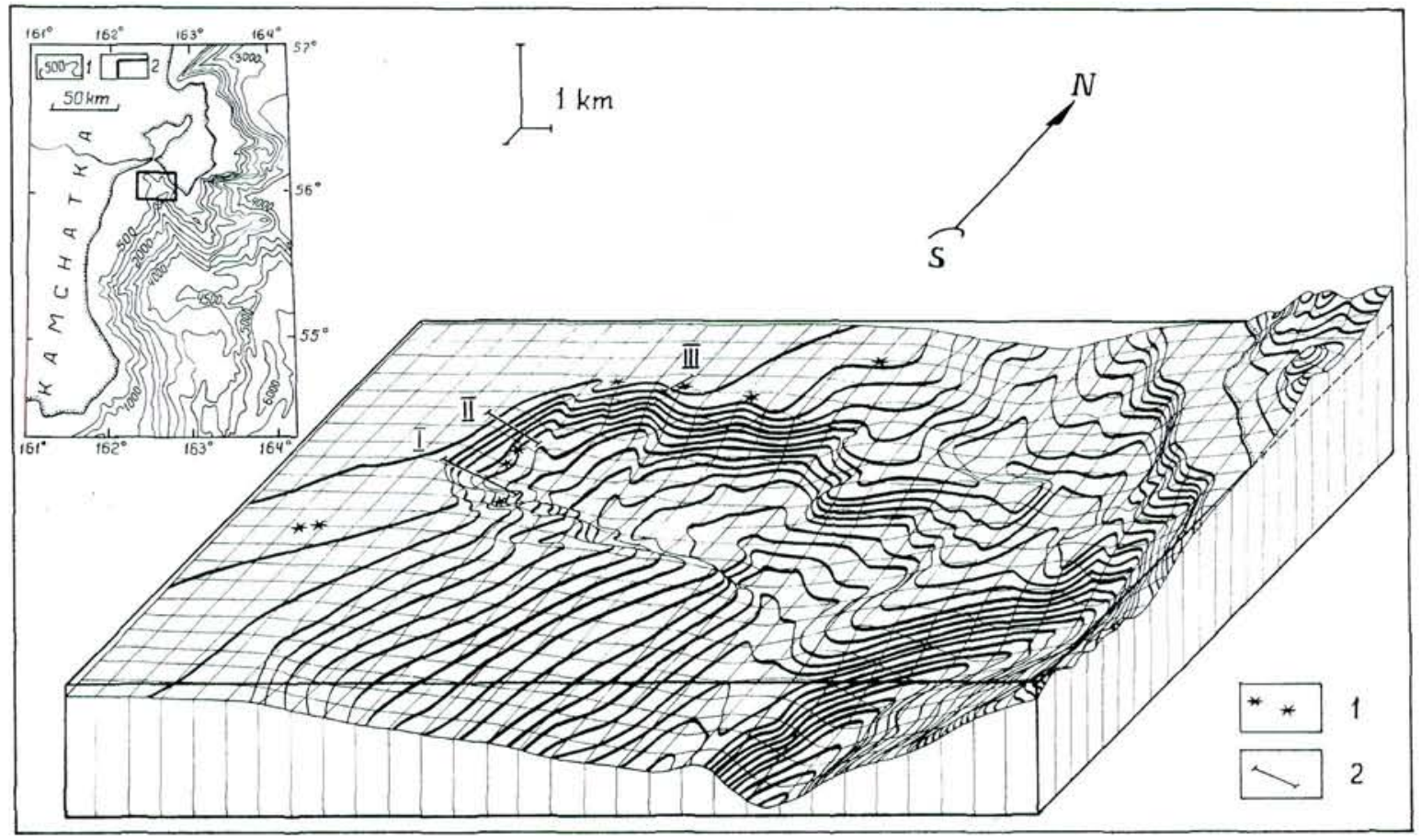

Fig. 2. Block diagram of the seafloor topography in the region under study. The position of the region is shown in the panel. Symbols in the block diagram: 1. gas plume orifices; 2 . portions of profiles for which examples of echograms are shown in Fig. 1; the position of profiles is reduced to sea level. Symbols in the panel: I. isobath $(\mathrm{m}) ; 2$. boundary of the region presented in the block diagram.

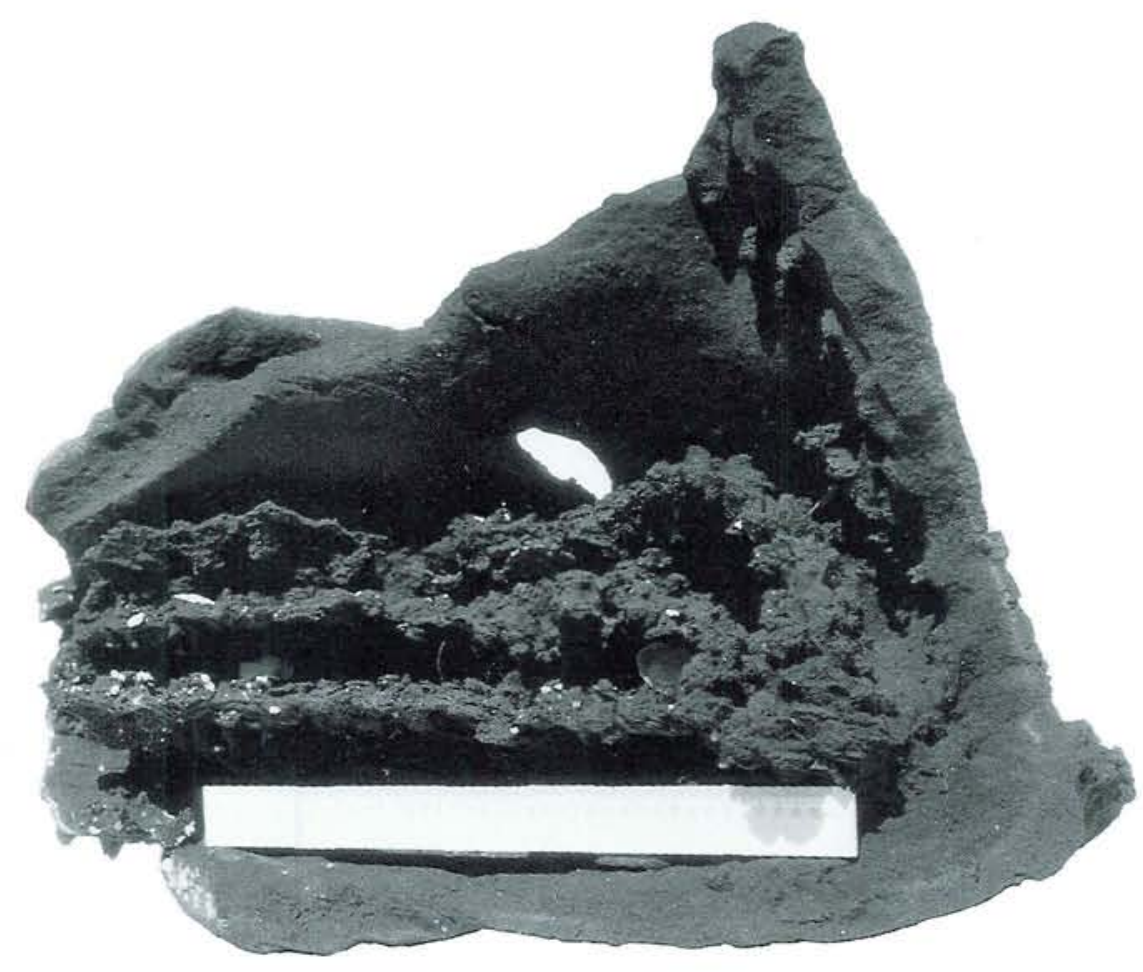

Fig. 3. Exotic sample of sandstone-carbonate assemblages recovered in a dredge near the gas plume at profile III. The ruler is 40 $\mathrm{cm}$ long. 
were dated on diatom remains to a cold period batween the Late Pleistocene and Holocene by E. G. Lupikina and L. M. Dolmatova. The conditions of clay formation were affected by the coastal-neritic zone of the sea and by river runoff. There is sufficient evidence to suggest that the valley was formed in the Upper Pleistocene-Holocene. The north-east wall of the valley, as distinct from the south-west wall, is composed of sandstones. Dark-coloured sandstones with carbonaceous cement were dredged on scarps of a shallow terrace at depths of 40-50 $\mathrm{m}$ in the immediate proximity to the north-east wall. Taking into account the different structures of the valley walls, we can propose that the position of the valley is controlled by a tectonic step with a north-west (Aleutian) trend. The south-west flank of this structure has subsided and is buried under young clay deposits and the northeast elevated flank is cut by the surface of the terrace. The age of sandstones that are exposed on the scarps of the terrace has not been established but these sandstones are assumed to be older than the clay deposits from the south-west wall of the valley.

Various kinds of material have been recovered from the surface of the terrace at the sites of gas plume detection. In addition to the debris of dark-coloured sandstones which we have just discussed, a great amount of live biota, as well as cemented sandstone debris of rather spectacular shapes (Fig. 3), and fragments of sandstonecarbonate crusts and concretions were recovered in the dredge. The latter are of interest as possible indicators of submarine fluid seepage (Hovland \& Judd 1988). The debris of these fragments are represented by quartz and plagioclase grains and are frequently enriched in remains of biota. Carbonaceous cements constituting from 10 to $35 \%$ by volume are composed of two phases: calcite (d: $3.029 \AA$ ) and Mg-calcite (d: 2.99-2.94 $\AA$ ). Among the minor minerals, illite (d: $9.93,4.47,2.56 \AA$ ) was found in the cement. Studies of the isotopic composition of carbon and oxygen of the calcite cement from crusts and concretions gave $\delta^{13} \mathrm{C}$ values ranging from -24.7 to $-62 \%$ o (PDB) and $\delta^{18} \mathrm{O}$ values with a range of $33.0-34.4 \%$ (SMOW). According to the present views (Hovland \& Judd 1988; Lein, Galchenko, Pokrovsky, Shabayeva, Chertkova \& Miller 1989), carbonate crusts and concretions form at sites of submarine fluid discharge, chiefly from the carbon of methane in the course of its bacterial oxidization. If we assume that the recovered crusts and concretions have the same origin, then it follows that the composition of fluids is dominated by methane with a high content of isotopically light carbon $\left(\delta^{13} \mathrm{C}\right.$ about $-70 \%$ PDB). Such a composition corresponds to "biogenic" methane which forms in the upper portions of sedimentary sections (Prasolov 1990).

\section{Conclusions}

Although our results do not give an unambiguous answer to questions concerning the composition of the fluids and the reasons for their discharge, an assumption can be made that fluid discharge is caused by tectonic activity. Ruptures formed in the sediment cover appear to act as conduits for deeply derived hydrothermal fluids. Also, due to the high seismicity of this region, gravitional-slide destruction of the sediment cover might occur. The Kamchatsky Gulf is a young non-compensated trough where an intense debris accumulation occurs both in the central part of the trough and on its downwarped walls. Rapid burial of organisc remains apparently creates favourable conditions in sediment layers for the generation and high concentration of biogenic methane which exits onto the seafloor through ruptures and week zones.

\section{Dansk sammendrag}

Der er konstateret submarine gasudslip i et større område på havbunden i Kamchatsky Bugten på relativ lav vanddybde (40-250 m). Tidligere unders $\varnothing$ gte gasudslip i den dybere del af farvandet ud for Kamchatka har kunnet relateres til hydrothermal aktivitet eller tilstedeværelsen af gashydrater $\mathrm{i}$ de underliggende sedimenter. Den her beskrevne forekomst af submarin gas synes imidlertid at være af biogen oprindelse.

Gassen består således hovedsagelig af methan med en kulstof isotopsammensætning på c. $-70 \%$ o $\delta^{13} \mathrm{C}$ PDB, hvilket tyder på at gassen er dannet som følge af biogen nedbrydning af organisk materiale $i$ de underliggende sedimenter. Kamchatsky Bugten udgør tektonisk set et ungt trug karakteriseret af relative høje sedimentationshastigheder og dermed mulighed for afsætning af sedimenter med stort organisk indhold.

I forbindelse med gasudslippene er der fundet betydelige mængder af karbonatcementerede marine sedimenter som regel i form af cementerede skorper og konkretioner. Karbonatcementen består både af calcit og Mg-calcit og har en ilt og kulstof isotopsammensætning på henholdsvis $+33.0-+34.4 \%$ o $\delta^{18} \mathrm{O}$ (SMOW) og $-24.7--62.0 \%$ o $\delta^{13} \mathrm{C}$ PBD. Denne isotopsammensætning tyder på, at karbonatcementen er dannnet som følge af bakterial nedbrydning af methan $i$ de $\emptyset$ verste lag af de marine sedimenter.

\section{References}

Avdeiko, G. P., Gavrilenko, G. M., Chertkova, L. V., Bondarenko, V. I., Rashidov, V. A., Guseva, V. I., Maltseva, V. I. \& Sazonov A. P. 1984: The submarine gas-hydrothermal activity on the north-west slope of Paramushir Island (Kurile Islands). Volcanol. and Seismol. 6, 66-81. [In Russian].

Hovland, M. \& Judd, A. G. 1988: Seabed pockmarks and seepages. London, Dordrecht, Boston, 293 pp.

Lein, A. Yu., Galchenko, V. F., Pokrovsky, B. G., Shabayeva, I. Yu., Chertkova, L. V. \& Miller, Yu. M. 1989: Marine carbonate concretions as a result of microbe oxidizing of gas-hydrothermal methane in the Sea of Okhotsk. Geokhimia 10, 1396-1406. [In Russian].

Nadezhny, A. M. \& Bondarenko, V. I. 1989: Gas hydrates from 
the Sea of Okhotsk (vicinities of Kamchatka-Paramushir Island). Dokl. Akad. Nauk 306, 5, 1192-1196. [In Russian].

Nadezhny, A. M., Seliverstov, N. I., Torokhov, P. V., Egorov, Yu. O., Dubrovsky, V. N., Taran, Yu. A., Kokarev S. G. \& Shkira, V. A. 1993: Seepages in the Kamchatsky Gulf Dokl. Akad. Nauk. 328, 1, 78-80.

Prasolov, E. M. 1990: Isotopic geochemistry and the origin of natural gases. Leningrad, Nedra, 282 pp. [In Russian].

Seliverstov, N. I., Baranov, B. V., Egorov, Yu. O. \& Shkira, V. A. 1988: New data on the structure of the southern Commander Basin obtained during cruise 26 of the R/V "Vulkanolog". Volcanol. and Seismol. 4, 3-20. [In Russian].

Seliverstov, N. I., Gavrilenko, G. M. \& Kirianov, V. Yu. 1989:
Indications of the present-day activity of Piip submarine volcano. Volcanol. and Seismol. 6, 3-18. [In Russian].

Torokhov, P. V., Taran, Yu. A., Sagalevich, A. M., Pokrovsky, B. G. \& Shabayeva, I. Yu. 1991: Isotopic composition of methane, carbon dioxide and carbonates from the thermal vents of Piip submarine volcano (Bering Sea). Dokl. Akad: Nauk 318, 3, 728-732. [In Russian].

Zonenshain, L. P., Murdmaa, I. O., Baranov, B. V., Kuznetsov, A. P., Kuzin, V. S., Kuzmin, M. I., Avdeiko, G. P., Stunzhas, P. A., Lukashin, V. N., Barash, M. S., Valyashko, G. M. \& Demina, L. P. 1987: A submarine gas source to the west of Paramushir Island (Sea of Okhotsk). Okeanologia 27, 5, 795800. [In Russian]. 